原 著論文

\title{
ジルコニアに対するセルフアドヒーシブレジンセメントの剪断接着強さ
}

岡本 和彦, 飯塚 知明, 猪野 照夫, 岩瀨 直樹, 佐藤 雅介, 藤澤 政紀

\section{The Shearing Bond Strength of Self-Adhesive Resin Cement to Dental Zirconia}

\author{
Kazuhiko Okamoto, DDS, PhD, Tomoaki Iizuka, DDS, Teruo Ino, DDS, PhD, Naoki Iwase, DDS, PhD, \\ Masayuki Sato, DDS and Masanori Fujisawa, DDS, PhD
}

\begin{abstract}
抄 録
目的：部分安定型ジルコニア（以下ジルコニアと略す）に対して，4 種類のセルフアドヒーシブレジンセ メントの剪断接着強さについて評価した。

方法：本研究には, 以下のセルフアドヒーシブレジンセメント, G-Luting, Clearfil SA luting, Rely X Unicem, Smartcem を用いた。被験試料には, ジルコニアを調製し, 常温重合レジン内へ包埋後, 被着 面研磨に耐水研磨紙＃600 を使用した。接着体には，ステンレスロッドを用い，被験試料数は，各セルフ アドヒーシブレジンセメントについて 14 個製作し，水中浸漬後ならびにサーマルサイクル試験後の剪断 接着強さならびに破壊樣相を評価した.

結果：セルフアドヒーシブレジンセメントのジルコニアに対する剪断接着強さは，水中浸漬後で $7.5 〜$ 66.1 MPa，サーマルサイクル試験後では， $0.8 〜 71.0 \mathrm{MPa}$ を示した. リン酸エステル系モノマー含有 のセルフアドヒーシブレジンセメントでは，カルボン酸系モノマー含有と比較して，剪断接着強さが高か った．破壊様相では，全被験試料でステンレスロッド界面での破壊は生じておらず，ジルコニア表面とセ メントとの界面破壊，あるいは，セメント内部での混合破壊であった.

結論: ジルコニアに対して, リン酸エステル系モノマーを含有するセルフアドヒーシブレジンセメントは, 剪断接着強さのうち加速劣化の影響を比較的受けにくいことが示唆された.
\end{abstract}

和文キーワード

セルフアドヒーシブレジンセメント, 部分安定化ジルコニア, リン酸エステル系モノマー

\section{I. 緒 言}

審美性を考慮した歯冠補綴装置の製作にあたり，従来 より機械的特性に優れるメタルボンドクラウンが応用さ れてきた。しかしながら，長期使用による経過観察から 金属色による光の不透過性や歯科金属アレルギーに対す る問題点などが指摘されるようになってきた。これらの 解決手段として, メタルフリーとなる口腔内環境を実現 するため, 歯冠補綴装置に応用される材料としてオール セラミックシステムが注目されるようになった。 さらに 歯科用 $\mathrm{CAD} / \mathrm{CAM}$ の進歩により, アルミナ, ジルコニ
アが普及し, 従来のシリカを主体としたオールセラミッ クの脆弱性が改良されるようになった。 なかでも，部分 安定型ジルコニアは, 生体親和性 ${ }^{1)}$ や審美性 ${ }^{2)}$, そして,

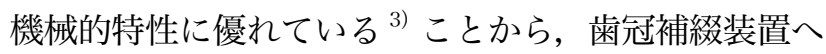
の応用頻度も高くなってきている ${ }^{4)}$.

一方, 審美的要求の高い補綴装置の装着にあたり, 支 台歯フィニッシュラインを歯肉縁下に設定することが多 いため，呼気や歯肉溝滲出液などに影響を受けることな く, 支台歯が乾燥状態下において合着操作を完了するこ とは難しい. したがって, 長期間にわたり合着用セメン トの機械的特性を維持し, 良好な術後経過を獲得するた めには，合着操作において煩雑な処理が少なく，短時間

明海大学歯学部機能保存回復学講座歯科補綴学分野

Division of Fixed Prosthodontics, Department of Restorative \& Biomaterials Sciences, Meikai University School of Dentistry

受付 : 2010 年 3 月 25 日/受理 $: 2010$ 年 8 月 30 日

Received on March 25, 2010/Accepted on August 30, 2010 
に完了することが必要である，昨今，臨床応用されてい るセルフアドヒーシブレジンセメントは，従来の接着性 レジンセメントに比較して口腔内環境の影響を受けにく く ${ }^{5)}$, 操作方法が簡便 ${ }^{6)}$ であるが，接着力に関しては, 同一接着環境下において接着性レジンセメントに応用さ れているマルチステップタイプに比較して, 歯質や歯冠 補綴材料に対して低いことが報告されている ${ }^{7)}$. 特に, 歯冠補経装置に部分安定型ジルコニアを応用した場合に は，従来型のシリカ含有セラミック材料と接着法が異な り, シリカが含有されていないためシランカップリング 処理のような単独表面処理法は無効とされ ${ }^{8)}$, 接着性モ ノマー含有の接着性レジンセメントの使用 ${ }^{7-15)}$, あるい は，部分安定型ジルコニアの被着表面に対してシリカ処 理などの表面処理 ${ }^{10-13,16-23)}$ を補綴装置内面に対して併 用することが接着耐久性を向上させるうえで有効である と報告されている。

しかしながら, セルフアドヒーシブレジンセメントと 部分安定型ジルコニアとの接着に関しては，ジルコニア 被着面に対する表面処理法の違いと接着強さに関する報 告が多くみられるが，ジルコニア被着面を未処理状態下 における水中浸漬ならびにサーマルサイクル試験を行い セルフアドヒーシブレジンセメントの接着強さに関して 検討を行ったものは比較的少ない ${ }^{12-15,23)}$.

そこで, 本研究では，4種類のセルフアドヒーシブレ ジンセメントと部分安定型ジルコニアとの接着強さおよ び接着耐久性について評価することを目的として，水中 浸漬後およびサーマルサイクル試験後の剪断接着強さの 測定，ならびに破壊様相を観察した。

\section{II. 研究方法}

本研究では, 以下の 4 種セルフアドヒーシブレジン セメントをメーカー指示の方法・条件にて使用した。そ の主成分を表 1 に示す。

(1) G-Luting : GL

(GC, Tokyo, Japan)

(2) Clearfil SA luting : SA

(KURARAY MEDICAL INC, Tokyo, Japan)

(3) Rely X Unicem : RU

(3M ESPE, Minnesota, USA)

(4) Smartcem : SM

(DENTSPLY SANKIN, Tokyo, Japan)

被着試料として, 部分安定化ジルコニア (Aadva Zirconia, GC, Tokyo, Japan. 以後, ジルコニア) を $16.0 \mathrm{~mm} \times 13.0 \mathrm{~mm} \times 3.0 \mathrm{~mm}$ に調製し, 常温 重合レジン (UNIFAST II，GC，Tokyo，Japan) 内
へ包埋した. ジルコニア材料の被着面に対して，耐水研 磨紙＃600を用いて最終研磨を行い，テフロンフィル ムを設置することにより規格化した被着面（直径 3.0 $\mathrm{mm}$, 厚さ $100 \mu \mathrm{m})$ を設定した。接着体としては, ステンレスロッド（直径 $10.0 \mathrm{~mm}$ ）を用い，被着面に 対して耐水研磨紙＃600にて研磨，サンドブラスト処 理 (噴射距離 $5 \mathrm{~mm}$, 噴射圧力 $0.4 \mathrm{MPa}$, 処理時間 1 秒) を行った後, 超音波にて洗浄した. ジルコニアとステン レスロッドとの接着には，4種類のセルフアドヒーシブ レジンセメントをメーカー指示に従って練和後, 被着試 料面上のテフロンフィルム接着規制部に対してセメント 泥を塗布，同上部よりステンレスロッドを手圧にて圧接 し，ただちに余剩セメントを除去後，セメント硬化まで 保持することによって被駼試料を製作した。

被験試料数は，各セルフアドヒーシブレジンセメント について 14 個製作し, セメント硬化後, $37^{\circ} \mathrm{C}$ 蒸留水中 に 23 時間保存の水中浸漬群 $(\mathrm{n}=7)$, さらにサーマル

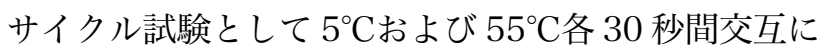
5000 回浸漬を行うサーマルサイクル群 $(n=7)$ を設 定した.

剪断接着強さの測定は，各被験試料を水中浸漬後なら びにサーマルサイクル試験後に専用治具内一固定し，オ ートグラフ (AG-IS，島津製作所，Kyoto，Japan）を 用いてクロスヘッドスピード $1.0 \mathrm{~mm} / \mathrm{s}$ の条件下で行 つた（図 1)。なお，結果は，剪断接着強さについて各 セルフアドヒーシブレジンセメントならびにサーマルサ イクル試験の有無について二元配置分散分析を用いて解 析 $(p<0.05)$ し，その後，Scheffé’s F testによる多 重比較検定を用いて統計処理 $(p<0.05)$ を行った。 こ れらの統計処理には, 統計解析ソフト (SPSS Statistics 17.0, SPSS Japan Inc, Tokyo, Japan) を使用した. また，接着面の破壊様相についての観察は，剪断接着強 さの測定後にデジタルマイクロスコープ (VHX-100F, KEYENCE，Osaka，Japan）を用いて行い，界面破壊 および混合破壊の 2 種類に分類した.

\section{III. 結 果}

水中浸漬群とサーマルサイクル群におけるジルコニア に対する各セルフアドヒーシブレジンセメントの剪断接 着強さを図 2 に示す。水中浸漬群において, 剪断接着 強さは, 7.5〜 66.1 MPaを示し, GLにおいて最も高く, GL と SM 間で有意差がみられた $(p<0.05)$ ものの, 他のセメント間においては有意差が認められなかった。 これに対してサーマルサイクル群において，剪断接着強 さは, $0.8 〜 71.0 \mathrm{MPa}$ を示し, GLにおいて最も高く, 
表 1 Self-adhesive resin cements used in this study 実験に使用したセルフアドヒーシブレジンセメント

\begin{tabular}{l|l|c}
\hline $\begin{array}{l}\text { Product (Shade) / Lot No. / } \\
\text { Manufacturer }\end{array}$ & Main composition & Code \\
\hline \hline $\begin{array}{l}\text { G-Luting (Translucent) / } \\
0810301 \text { (A paste) } \\
0811050 \text { (B paste) / GC }\end{array}$ & $\begin{array}{l}\text { Fluoro-alumino-silicate glass, Silicon dioxide, } \\
\text { Dimethacrylate resin, Phosphoric acid ester } \\
\text { monomer }\end{array}$ & GL \\
\hline Clearfil SA luting (Universal) / & $\begin{array}{l}\text { Bis-GMA, TEGDMA, MDP, barium glass, } \\
\text { glass, silica, sodium fluoride }\end{array}$ & SA \\
\hline Re064A / Kuraray Medical & $\begin{array}{l}\text { dimethacrylate, acetate, methacrylated } \\
\text { phosphoric ester, glass powder, silica, calcium } \\
\text { 335523 / 3M-ESPE }\end{array}$ & RU \\
\hline Smartcem (Natural) / & $\begin{array}{l}\text { methacrylic acid 2-hydroxyethyl, HEMA, } \\
\text { Trimellitic acid, 4-MET, PENTA, PEM-F, }\end{array}$ & SM \\
& BDMA, sulfinate & \\
\hline
\end{tabular}

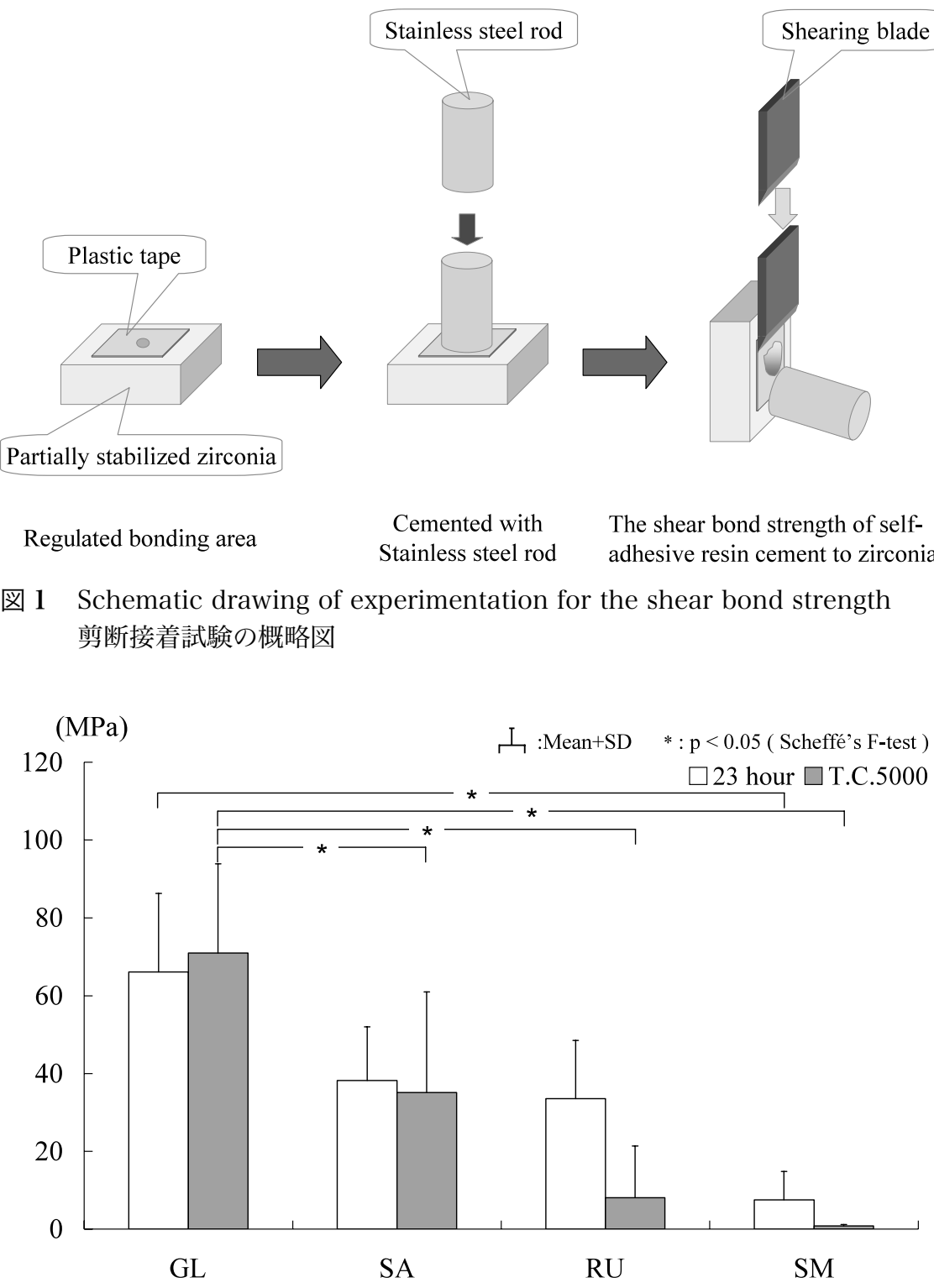

図 2 Mean shear bond strength and standard deviation of means of selfadhesive resin cements セルフアドヒーシブレジンセメントの剪断接着強さ 
表 2 Results of 2-way analysis of variance 二元配置分散分析の結果

\begin{tabular}{l|c|r|r|r|r}
\hline \multicolumn{1}{c|}{ Source of variation } & $\mathrm{d} f$ & Sum of squares & Mean square & $F$-value & $P$ value \\
\hline \hline Thermocycled condition (A) & 1 & 812.833 & 812.833 & 2.890 & 0.096 \\
\hline Cement type (B) & 3 & 31593.570 & 10531.190 & 37.442 & $<0.001$ \\
\hline A B & 3 & 1734.420 & 578.140 & 2.055 & 0.119 \\
\hline Error & 48 & 13500.822 & 281.267 & & \\
\hline Total & 56 & 106907.090 & & & \\
\hline
\end{tabular}

GL と SA，RU，SM間において有意差が認められた（ $p$ $<0.05)$. サーマルサイクル群における剪断接着強さは, 水中浸漬群に比較して GL で増加傾向を示したのに対し て, SA, RU と SM においては減少する傾向がみられた。 また，表 2 に示すようにセルフアドヒーシブレジンセ メントの種類, サーマルサイクル試験の有無において, それぞれ有意差が認められた $(p<0.05)$.

剪断接着試験後における被着界面での破壊様相の観察 では，ステンレスロッド界面において，いずれの被験試 料にも破壊が生じておらず，ジルコニア表面と合着用セ メントにおける界面破壊，あるいは，合着用セメント内 における混合破壊か認められた。 また，水中浸漬群にお いて，SA，RU，SMでは，セメント界面での接着破壊 が多く, さらにサーマルサイクル群において, SA, RU および SM では，すべて界面破壊が観察された。これ に対して，GLでは，混合破壊が多くみられ，水中浸漬 群とサーマルサイクル群において, 混合破壞の割合がい ずれも57\%であった（図 3).

\section{IV. 考 察}

間接法によって製作された歯冠補綴装置は，合着材を 介在することによって支台歯へ装着されるが，口腔内は 多湿環境下であるため, 装着時における合着用セメント の機械的性質や取り扱い方法を考慮しながら選択, 装着 することが重要である．特に審美性を重視した歯冠補綴 装置においては，支台歯フィニッシュラインの設定位置 を歯肉縁下とすることが多く, 乾燥状態の確保に対して, さらなる配慮が必要となるため, 歯冠補綴装置の合着に あたっては，取り扱い方法が簡便であり，装着環境下の 影響を受けることによっても機械的性質変化の少ない合 着材を選択することが望ましいと思われる，セルフアド ヒーシブレジンセメントは, 歯冠補綴装置の装着にあた り, 従来の接着性レジンセメントと比較して, 操作性が 簡便である ${ }^{6)}$ ため，術者の熟練度による影響を受けに くい5)ことか報告されている.
一方，合着用セメントの機械的性質のうち，被着体に 対する接着強さに関しては，表面処理状態，合着材の種 類，そして，保存状態に影響を受けることか蕔告されて いる ${ }^{12)}$. なかでも, 従来から長期間水中保存とサーマ ルサイクル試験は, 臨床的に関連性のある実験とされて おり ${ }^{7)}$ ，また，長期間水中保存は，接着性レジンセメン 卜の化学的耐久性を把握する手段として有効である ${ }^{13)}$. さらに，乾燥条件下における試験に比較して，水中保存 やサーマルサイクル試験を条件設定として加えた場合

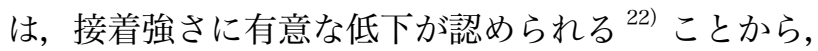
口腔内の多湿環境下における合着用セメントの機械的性 質について把握するには，水中保存やサーマルサイクル 試験を条件設定として用いて評価することが妥当と考え られた。そこで本実験では，セルフアドヒーシブレジン セメントにおける剪断接着強さの測定にあたり，臨床的 パラメーターとして, 水中浸漬およびサーマルサイクル 試験による加速劣化試験を負荷することにより，審美補 綴修復に用いられるオールセラミッククラウン修復材料 のうち，ジルコニアに対するセルフアドヒーシブレジン セメントの剪断接着強さの検討を行つた.

ジルコニア被着面に対する接着性モノマーを用いた表 面処理ならびに接着性モノマー含有のセルフアドヒーシ ブレジンセメントでは，金属酸化物であるジルコニアに 対して接着性が向上し $\left.{ }^{7}, 12-15,19\right)$ ，さらに被着表面に対 する表面処理を行うことなく接着力を向上する ${ }^{12-15)} こ$ とか蕔告されている。本実験結果では，水中浸漬後にお ける剪断接着強さが $\mathrm{GL} ， \mathrm{SA}$ ，そして，RU 間において 有意差はみられなかったのに対して，GL と SM間で有 意差が認められた。これは，GL，SA，そして，RUに 含有している接着性モノマーが疎水性のリン酸エステル 系モノマーであるのに対して SM では，親水性のカル ボン酸系モノマーを含有していることから，これら接着 性モノマーの特性に起因したものと考えられる. Oyagüe ら ${ }^{13)}$ は，ジルコニア被着面に対するセルフア ドヒーシブレジンセメントの水中浸漬 24 時間後におけ る引張り接着強さについての実験を行い，ジルコニア被 


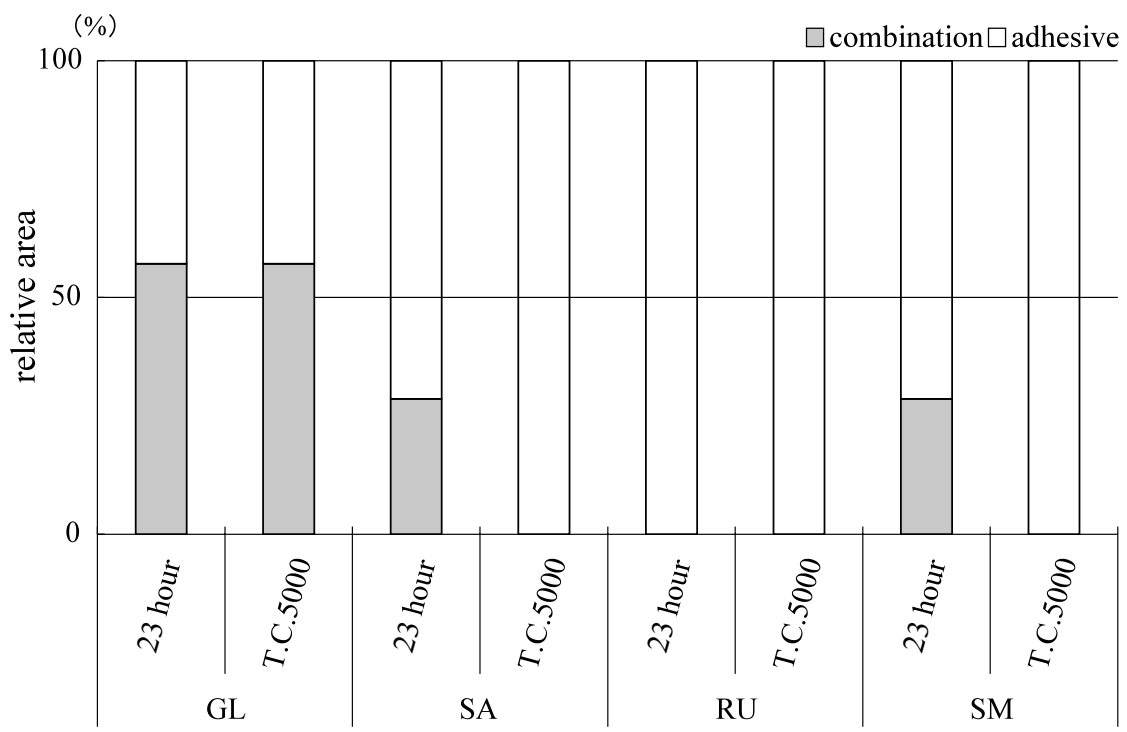

図 3 Mean percentage of areas assigned to the failure mode at the shear bond test

剪断接着試験における破断様式の割合

着面に対して表面処理を行わなくとも接着強さの向上に MDP が有効であり，これは，疎水性特性により加水分 解を生じにくくすることに起因していると報告してい る。また，カルボン酸系接着性モノマーを含有したセル フアドヒーシブレジンセメントでは，ジルコニアの表面 処理を行わない場合において，リン酸エステル系モノマ 一に比較して接着強さが低い ${ }^{13)}$ ことも報告しており, これらのことから本実験では，セルフアドヒーシブレジ ンセメントに含有している接着性モノマーの違いが水中 浸漬群の剪断接着強さに影響しているものと思われた。

サーマルサイクル群における剪断接着強さでは, GL が最も高く，水中浸漬後と比較して剪断接着強さがわず かに向上した. リン酸エステル系モノマー含有の接着性 レジンセメントならびにセルフアドヒーシブレジンセメ ントの剪断接着強さは, 水中浸漬後と比較してサーマル サイクル試験後において向上する ${ }^{7,17)}$ ことが報告され ており，GLにおいても同様な結果か認められた。 セル フアドヒーシブレジンセメントがジルコニアの剪断接着 強さに及ぼす要因としては，合着用セメント硬化体の強 度，接着性モノマー量および機能性モノマーの構造が考 えられ，なかでも，接着性モノマー含有量の増加は，接 着性を向上させる一方で，セメント硬化体の機械的性質 低下を招くため，相対的に剪断接着強さの向上に反映さ れないと考えられる。 また，アドヒーシブセメント成分 中のメタクリレート基は，水中浸漬中，あるいはサーマ ルサイクル試験負荷によって, 残留重合, 重合促進を生 じることが報告されている ${ }^{24)}$ 。これらのことから，接
着性モノマー量の配合率, セメント硬化体の機械的強度, そして, 残留重合および重合促進，これらの因子が作用 した結果，サーマルサイクル群の GLにおいて剪断接着 強さがわずかに向上したものと推察できる。

水中浸漬後における破壊様相は，GL 以外で界面破壊 の割合が混合破壊に比較して多くみられた。さらに，サ ーマルサイクル群においては，GL で界面破壊と混合破 壊の割合が同一であったものの，他のセルフアドヒーシ ブレジンセメントでは，すべて界面破壊であった。 Oyagüe ら ${ }^{14)}$ は，リン酸エステル系モノマーを含有し た RU を用いて，ジルコニア被着面に対して表面処理を 行うことなしに水中浸漬 24 時間後と 6 力月後の破壊様 相について観察したところ，時間経過に伴って混合破壊 が少なくなるのに対して, 界面破壊が多く認められたと 報告している。 また，Phark ら ${ }^{23)}$ は，レジンセメント を用いてジルコニア被着面に対して表面処理をせずに水 中保存 90 日，さらにサーマルサイクル試験 20000 回 負荷後の破壊様相を観察し，被験試料 10 個中 9 個に接 着不良が観察されたことを報告している，水中浸漬なら びに加速劣化試験は，ジルコニアに対するレジンセメン トの接着強さを低下させる ${ }^{12,17,21,23)}$ 。一方で，Ozcan $ら^{16)}$ は，接着性レジンセメントを用いてジルコニア被 着面に対する剪断接着強さに関してサーマルサイクル試 験 6000 回負荷後の破壊样相の観察において長期予後を 推察することが難しいことを報告している.

今回設定した水中浸漬時間ならびにサーマルサイクル 試験 5000 回浸漬負荷において，GL では，混合破壊の 
割合が同一となったことから，他のセルフアドヒーシブ レジンセメントに比較して機械的性質が優れていると考 えられる.しかしながら, 水中浸漬時間の延長やサーマ ルサイクル試験の負荷回数増加による,さらなる加速劣 化試験を行い検討する必要があると思われた。

\section{V. 結 論}

ジルコニア系セラミックス材料に対する 4 種類のセ ルフアドヒーシブレジンセメントの接着強さおよび接着 耐久性について検討するため, 水中浸漬 23 時間後なら びにサーマルサイクル試験 5000 回浸漬後における剪断 接着強さならびに破壊様相について評価を行つた。その 結果, 部分安定型ジルコニアに対してリン酸エステル系 モノマーを含有するセルフアドヒーシブレジンセメント では，剪断接着強さにおいて加速劣化による影響を比較 的受けにくいことが示唆された。

\section{文献}

1) Yamashita D, Machigashira M, Miyamoto $M$, Takeuchi H, Noguchi K, Izumi Y et al. Effect of surface roughness on initial responses of osteoblast-like cells on two types of zirconia. Dent Mater J 2009; 28: 461-470.

2) Schmitter M, Mussotter $K$, Rammelsberg $P$, Stober T, Ohlmann B, Gabbert O. Clinical performance of extended zirconia frameworks for fixed dental prostheses: two-year results. J Oral Rehabil 2009; 36: 610-615.

3) Studart AR, Filser F, Kocher P, Gauckler LJ. Fatigue of zirconia under cyclic loading in water and its implications for the design of dental bridges. Dent Mater 2007; 23: 106-114.

4) Sadan A, Blatz MB, Lang B. Clinical considerations for densely sintered alumina and zirconia restorations: Part 1. Int J Periodontics Restorative Dent 2005; 25: 213-219.

5) Radovic I, Monticelli F, Goracci C, Vulicevic ZR, Ferrari M. Self-adhesive resin cements: a literature review. J Adhes Dent 2008; 10: 251-258.

6) Han L, Okamoto A, Fukushima M, Okiji T. Evaluation of physical properties and surface degradation of self-adhesive resin cements. Dent Mater J 2007; 26: 906-914.

7) Lüthy $\mathrm{H}$, Loeffel $\mathrm{O}$, Hammerle $\mathrm{CH}$. Effect of thermocycling on bond strength of luting cements to zirconia ceramic. Dent Mater 2006; 22: 195200.

8) Yoshida K, Tsuo Y, Atsuta M. Bonding of dualcured resin cement to zirconia ceramic using phosphate acid ester monomer and zirconate coupler. J Biomed Mater Res B Appl Biomater 2006; 77: 28-33.

9) Atsu SS, Kilicarslan MA, Kucukesmen HC, Aka PS. Effect of zirconium-oxide ceramic surface treatments on the bond strength to adhesive resin. J Prosthet Dent 2006; 95: 430-436.

10) Wolfart M, Lehmann F, Wolfart S, Kern M. Durability of the resin bond strength to zirconia ceramic after using different surface conditioning methods. Dent Mater 2007; 23: 45-50.

11) Tsuo Y, Yoshida K, Atsuta M. Effects of aluminablasting and adhesive primers on bonding between resin luting agent and zirconia ceramics. Dent Mater J 2006; 25: 669-674.

12) Blatz MB, Chiche G, Holst $S$, Sadan A. Influence of surface treatment and simulated aging on bond strengths of luting agents to zirconia. Quintessence Int 2007; 38: 745-753.

13) Oyagüe RC, Monticelli F, Toledano M, Osorio E, Ferrari M, Osorio R. Influence of surface treatments and resin cement selection on bonding to densely-sintered zirconium-oxide ceramic. Dent Mater 2009; 25: 172-179.

14) Oyagüe RC, Monticelli F, Toledano M, Osorio E, Ferrari M, Osorio R. Effect of water aging on microtensile bond strength of dual-cured resin cements to pre-treated sintered zirconium-oxide ceramics. Dent Mater 2009; 25: 392-399.

15) Blatz MB, Phark JH, Ozer F, Mante FK, Saleh N, Bergler $\mathrm{M}$ et al. In vitro comparative bond strength of contemporary self-adhesive resin cements to zirconium oxide ceramic with and without air-particle abrasion. Clin Oral Investig 2010; 14: 187-192.

16) Ozcan M, Vallittu PK. Effect of surface conditioning methods on the bond strength of luting cement to ceramics. Dent Mater 2003; 19: 725731.

17) Blatz MB, Sadan A, Martin J, Lang B. In vitro evaluation of shear bond strengths of resin to densely-sintered high-purity zirconium-oxide ceramic after long-term storage and thermal cycling. J Prosthet Dent 2004; 91: 356-362.

18) Piwowarczyk A, Lauer HC, Sorensen JA. In vitro shear bond strength of cementing agents to fixed prosthodontic restorative materials. J Prosthet Dent 2004; 92: 265-273.

19) Piwowarczyk A, Lauer HC, Sorensen JA. The shear bond strength between luting cements and zirconia ceramics after two pre-treatments. Oper Dent 2005; 30: 382-388. 
20) Bottino MA, Valandro LF, Scotti R, Buso L. Effect of surface treatments on the resin bond to zirconium-based ceramic. Int J Prosthodont 2005; 18: 60-65.

21) Amaral R, Ozcan M, Bottino MA, Valandro LF. Microtensile bond strength of a resin cement to glass infiltrated zirconia-reinforced ceramic: the effect of surface conditioning. Dent Mater 2006; 22: 283-290.

22) Valandro LF, Ozcan M, Amaral R, Leite FP, Bottino MA. Microtensile bond strength of a resin cement to silica-coated and silanized In-Ceram Zirconia before and after aging. Int J Prosthodont 2007; 20: 70-72.

23) Phark JH, Duarte S Jr, Blatz M, Sadan A. An in vitro evaluation of the long-term resin bond to a new densely sintered high-purity zirconium-oxide ceramic surface. J Prosthet Dent 2009; 101: 2938.

24) Pace LL, Hummel SK, Marker VA, Bolouri A. Comparison of the flexural strength of five adhesive resin cements. J Prosthodont 2007; 16: $18-24$.

著者連絡先 : 岡本 和彦

干 350-0283 埼玉県坂戸市けやき台 1-1

TEL: 049-285-551 1

FAX: 049-287-6657

E-mail: okamoto@dent.meikai.ac.jp 


\title{
The Shearing Bond Strength of Self-Adhesive Resin Cement to Dental Zirconia
}

\author{
Kazuhiko Okamoto, DDS, PhD, Tomoaki Iizuka, DDS, Teruo Ino, DDS, PhD, Naoki Iwase, DDS, PhD, \\ Masayuki Sato, DDS and Masanori Fujisawa, DDS, PhD
}

Division of Fixed Prosthodontics, Department of Restorative \& Biomaterials Sciences, Meikai University School of Dentistry

Ann Jpn Prosthodont Soc $3:$ 32-39, 2011

\section{ABSTRACT}

Purpose: To evaluate the shear bond strength and bonding durability of different self-adhesive resin cements to dental zirconia.

Method: The following self-adhesive resin cements were used in this study: G-luting, SA luting, RelyX Unicem and Smartcem. The specimens of zirconia were embedded into acrylic resin. Each specimen was then cemented in bonding area that was regulated with plastic tape $(3.0 \mathrm{~mm}$ in diameter) using self-adhesive resin cement (self-curing mode) with a stainless steel rod (10 $\mathrm{mm}$ in diameter), after it was prepared using wet 600-grits silicone carbide paper. Each self-adhesive resin cement was prepared for each of the 14 specimens. Prior to performing the shear bond strength test, all bonded specimens $(n=14)$ were stored at $37^{\circ} \mathrm{C}-100 \%$ relative humidity for 1 hour and stored in $37^{\circ} \mathrm{C}$ distilled water for 23 hours. Half the specimens $(n=7)$ were repeatedly thermal cycled for 5000 cycles between $5^{\circ} \mathrm{C}$ and $55^{\circ} \mathrm{C}$. The shear bond strength of self-adhesive resin cement to zirconia was measured in a universal testing machine.

Results: The mean shear bond strength of the self-adhesive resin cements to zirconia varied from 7.5 to $66.1 \mathrm{MPa}$ after storage in $37^{\circ} \mathrm{C}$ distilled water for 23 hours, and from 0.8 to $71.0 \mathrm{MPa}$ after repeated thermal cycling. The shear bond strengths of the self-adhesive resin cements containing phosphoric acid ester monomer were slightly higher than for those containing carboxyl acid monomer. Observation of fracture mode determined that fractures did not occur at the interface with the stainless steel rods. All fractures occurred either at the interface between the zirconia surface and the cement (adhesive mode) or within the cement (cohesive mode).

Conclusion: Self-adhesive resin cements containing adhesive monomers such as phosphoric acid ester monomer showed slightly less accelerative degradation than other cements when bonded to dental zirconia.

\section{Key words}

self-adhesive resin cement, partially stabilized zirconia, phosphoric acid ester monomer 